https://doi.org/10.25143/socr.13.2019.1.022-029

\title{
Uz sabiedrību vērsta policijas darba metodes mūsdienu mainīgajā pasaulē
}

\author{
Mg. iur., LL.M Ilze Bērzina-Rukere \\ Rìgas Stradiṇa universitāte, Juridiskā fakultāte, Latvija \\ propoliceilze@gmail.com
}

\section{Kopsavilkums}

Publikācijā tiek skatītas noziedzības prevencijas mūsdienu metodes un policijas darbs ar sabiedrību Latvijā. Tiek sniegts atskats uz policijas darba metožu nozīmīgākajām pārmaiṇām pēdējā desmitgadē un centieniem ieviest jaunus komunikācijas paṇēmienus, lai efektīvāk uzrunātu iedzīvotājus. Akcentēti veiksmīgākie projekti un iniciatīvas, apliecinot, ka aizvadìtajos desmit gados sperts nozīmīgs solis ceḷa uz mūsdienīgu policijas dienestu: mainìta Valsts policijas darba organizācija un īstenoti daudzi projekti. Taču ikdienā netrūkst piemēru, ka kibernoziegumu un citu noziedzīgo nodarïjumu apkarošanai būs nepieciešams milzum daudz aktivitāšu arī turpmāk. Situācija liek mainīt policijas rīcību un meklēt alternatīvas noziedzības prevencijas metodes.

Atslēgvārdi: uz sabiedrību vērsts policijas darbs, Valsts policija, noziegumu prevencija, kibernoziegumi.

\section{levads}

Šì publikācija sagatavota vēsturiskā brīdī, kad tiek svinēta Rīgas Stradiṇa universitātes Juridiskās fakultātes 10. gadskārta. Aizvadītie desmit gadi īpaši nozīmīgi bija arī Latvijas Valsts policijai, kuru gandrīz pilnībā skāra pārmaiṇu procesi. Nedaudz pakavēšos pie zīmīgākajiem pieturpunktiem šajā laikposmā un atziṇām par pozitīvajām tendencēm, mainot policijas darbu uz sabiedrībai tuvāku un saprotamāku. Pievērsǐšos jautājumiem par Valsts policijas komunikāciju noziedzības prevencijas nolūkā, lai apkarotu pieaugošo noziedzību arī interneta vidē.

${ }^{1}$ LL.M (Legum Magister) - akadēmiskais tiesību zinātṇu maǵistra grāds, kas iegūts ārzemēs. 
Pārmaiṇu gadi un krīze, kas sākās 2008. gadā un nesa izaicinājumus visām Iekšlietu ministrijas struktūrvienībām, radīja gan zaudējumus, gan iespējas. Šoreiz varbūt mazāk par skumjajiem notikumiem un to sekām, ${ }^{2}$ bet vairāk par iespējām un izaicinājumiem, kas valsts iestādēm, īpaši Valsts policijai, lika pozitīvi mainīties - vairāk meklēt atbalstu un pievērsties sadarbībai, saskarsmi veidot jau uz citiem principiem un ar jaunām, nedaudz aizmirstām, kā arī alternatīvām policijas preventīvā darba metodēm.

Pārskatot policijas darba funkcijas un finanšu resursu izlietošanu, daudz pamatotu jautājumu radās arī par to, kā sabiedrība vērtē policijas darbu un resursu patēriṇa lietderību. Kas ir svarīgi iedzīvotājiem un kas - pašai Valsts policijai? Valsts policijas darbinieki vēlas saṇemt novērtējumu par smago darbu, ko veic, riskējot ar dzīvību un veselību, turpretī iedzīvotāji grib saprast un redzēt, ka policija strādā viṇu interesēs, viṇu apkaimē, ka tā ir pieejama. Tieši pieejamība, saprotama komunikācija un drošības sajūta mūsdienās ir un būs svarīga iedzīvotājiem [9, 16-38]. İpaši nozīmīgi tas ir steidzīgā dzīves ritma dēḷ. Daudzi cilvēki nelasa drukātos preses izdevumus, neskatās televīzijas pārraides un jaunumus uzzina tikai no virsrakstiem interneta vietnēs vai no sociālajiem tīkliem. Policijas vērtējums rodas no izpratnes un informācijas pieejamības par to, ko īsti policija dara katra iedzīvotāja labā. Tas tika visnotal pierādìts Talsu pilotprojektā [10], un kopš 2009. gada Valsts policijā tiek veiktas sociolog̣iskās aptaujas par iedzīvotāju uzticēšanos Valsts policijai. Jaunākie dati rāda, ka Valsts policijai uzticas $70 \%$ iedzīvotāju [23]. Ar jaunu pieeju un koncepciju darbam pēc projekta beigām un pēc Valsts policijas attīstības koncepcijas izstrādes 2013. gada nogalē izveidots Valsts policijas Prevencijas vadības birojs, kuram tika uzdots jaunās metodes ieviest dzīvē. Prevencijas darbs šobrīd ir ietverts visos Valsts policijas svarīgākajos plānošanas dokumentos [4]. Valsts policijas Prevencijas stratēgijā 2018.-2020. gadam, piemēram, ir iekḷauta ideja par iecirkṇu prevencijas plānu izstrādi un vides dizainu kā modernu metodi noziedzības mazināšanai. ${ }^{3}$

Mūsdienu steidzīgajā laikā aizvien svarīgāka kḷust policijas pieejamība, policija kā pakalpojumu sniedzēja cietušajiem [8] un sabiedrībai un saprotama komunikācija ar šo institūciju. Šo plānu sekmīga îstenošana dzìvē ir atkarīga no liela skaita policijas darbinieku, kam vajadzīgas nepieciešamās iemaņas un entuziasms, lai mainītu pieeju darbam. Nenoliedzami, jāturpina uzlabot arī policijas darba vērtēšanas kritēriji. Par tiem jau sen tiek runāts, bet sistēmas pārkārtošana norit diezgan lēni, jo nepieciešamais dažādu dokumentu noformēšanas apjoms palicis visai nemainīgs. Protams, svarīgi, ka plānošanas dokumentos iedzīvināta ideja par policijas darbu, kas vērsts uz sabiedrību, un pamazām ikdienas darba organizācijā izmaiṇas notiek, un pat tiesas atsaucas uz šo pieeju. Piemēram, Administratīvās rajona tiesas spriedumā par Rìgas pašvaldības policijas darbu un uzlikto sodu iedzīvotājam norādìts, ka "policijas uzdevums vispirmām

2 Latvijas Policijas akadēmijas likvidācija ir unikāls notikums ES dalībvalstī. Akadēmija tika likvidēta ar LR iekšlietu ministres Lindas Mūrnieces rīkojumu 2009. gada 25. maijā.

3 Valsts policijas prevencijas stratēgiskie darba virzieni 2018.-2020. gadam: Valsts policijas dokuments. Nav publicēts. 
Ilze Bērziņa-Ruḳere. Uz sabiedrību vērsta policijas darba

metodes mūsdienu mainīgajā pasaulē

kārtām nav represīva darbība un pārkāpēju sodīšana, bet gan likumpārkāpumu novēršana un atvērta sabiedriskā sevisa nodrošināšana. Ar policijas vērtību sistēmu mūsdienīgā izpratnē galvenokārt ir saistītas community policing jeb uz sabiedrību vērsta policijas darba idejas" [3].

Kopš 2013. gada Valsts policijā vairāk tiek domāts par dažādām, citādām un modernām policijas prevencijas un komunikācijas metodēm, kuras ìstenojot, piemēram, tiek uzturēta gan Valsts policijas mājaslapa [17], kā arī izveidota ìpaša mājaslapa Mana drošǐba [18], gan arī policijai ir savs konts Twitter, Facebook, Instagram, Draugiem.lv un Youtube. Tos Valsts policijas Sabiedrisko attiecību nodaļa izveidoja 2011. gadā. Pirms tam bija tikai veiksmīga sadarbība ar visiem šo sociālo tīklu uzturētājiem, bet Valsts policijai savu sociālo kontu nebija.

L,oti veiksmīgs bija viens no pirmajiem sadarbības pasākumiem, kas notika Eiropas Komisijas (EK) atbalstītajā projektā "Tu lieto narkotikas, narkotikas lieto tevi!”. Aktivitātes būtība bija šāda: gadījumā, ja jaunietis bija atbildējis, ka pamēgināt narkotikas ir forši, viṇa sociālo kontu policija "arestēja" līdz brīdim, kad meitene vai puisis iepazinās ar Valsts policijas mājaslapā publiskoto informāciju par narkotiku ietekmi uz veselību un juridisko atbildību. [13]

Valsts policija piedalās arī visos lielākajos mūzikas festivālos un ikgadējā sarunu festivālā LAMPA Cēsu pils parkā [22]. Tajos pulcējas ne tikai nevalstisko organizāciju un biznesa pārstāvji, bet arī valsts pārvaldes darbinieki, kuri arī izmanto modernos un atraktīvos saziņas paṇēmienus, lai kḷūtu tuvāki iedzivotājiem un skaidrotu arī aktuālās drošības tēmas.

Valsts policija 2018. gadā festivālā $L A M P A$ pārsteidza klausītājus ar interesantām diskusijām un uzstāšanās veidu. Policijas eksperti uzrunāja dalībniekus par vairākām aktualitātēm, arī par kibernoziegumu prevenciju un apkarošanu. Sarunā viṇi iesaistīja savus sadarbības partnerus - Drošāka interneta centru un sociālo tīklu guru Artūru Medni. Diskusijas laikā dalībniekiem tika dota iespēja uzzināt, ko par viṇiem var atrast sociālajos tīklos, brīvi meklējot informāciju. Ar informācijas meklēšanu gan nodarbojās profesionāli policijas darbinieki, bet tikai likuma atḷautajās robežās ${ }^{4}$ ar internetā brīvi pieejamiem līdzekḷiem. Organizējot pasākumu, tika gādāts, lai katru brīvprātīgo iepazīstinātu ar viņa tiesībām atteikties no informācijas publiskošanas, ja dalībnieks nevēlas, lai eksperimenta rezultātus uzzina plašs klausītāju loks. Cilvēku interese par šo nestandarta pieeju bija negaidīti liela, pat tik liela, ka dažiem interesentiem vajadzēja atteikt. Kāds ir secinājums? Cilvēkus piesaista iespēja satikt policijas darbiniekus neierastā vidē un neierastos apstākḷ̆os. Policija iedzīvotājiem var ne tikai dāvināt suvenīrus, bet arī dalīties ar savām zināšanām. Tas tiek augstu novērtēts, un tādējādi tiek celts policijas prestižs.

${ }^{4}$ Neilgi pirms pasākuma norises spēkā stājās Eiropas Parlamenta un Padomes Regula (ES) 2016/679 par fizisku personu aizsardzību attiecībā uz personas datu apstrādi un šādu datu brīvu apriti un ar ko atceḷ Direktīvu 95/46/EK (Vispārīgā datu aizsardzības regula) par to, ka publiskajos un citos pasākumos dati tiek izmantoti tikai ar datu subjekta piekrišanu. 
Ĺoti veiksmīgs solis saziṇā ar iedzīvotājiem ir Valsts policijas mobilās aplikācijas Mana drošǐba $a^{5}$ izveide 2016. gada nogalē [18]. Pirmo reizi iedzīvotāji ar aplikācijas starpniecību varēja ziṇot par cel̦u satiksmes negadījumiem, nosūtīt attēlus un pildīt drošības testus. İpaša uzmanība, izstrādājot aplikāciju, tika pievērsta drošîbai, policijas un ārkārtas dienestu izsaukšanai un iespējai nosūtìt koordinātes palīdzības dienestiem. Aplikācija izpelnījās lielu sabiedrības interesi un atbalstu [19]. Tà tika uzlabota 2018. gadā, kad aplikāciju papildināja sadal̦a par drošību interneta vidē. Iedzīvotājiem šobrīd ir iespēja nosūtìt ekrānuzṇēmumus, ziņot par kibernoziegumiem un sazināties ar palīdzības sniedzējiem, izmantojot mobilo tālruni vai rakstot e-pastu [21]. Šāda iespēja ir tikai dažās ES dalībvalstīs, un Valsts policijas iniciatīva vērtējama loti pozitīvi. Iedzīvotāji to loti plaši izmanto, viṇi labprāt fotografē dažādus notikumus un situācijas, kas varētu radìt nepieciešamību vērsties policijā pēc palīdzības.

Pieaugošie riski saistībā ar kibernoziegumu izplatīšanos nav mìts, un policijai tie nav vienaldzīgi, tomēr ne visos gadījumos izdodas apsteigt noziedzniekus. Saskaṇā ar Eiropola datiem palielinās dažāda veida krāpšanu, bankas datu viltošanas vai nelikumīgas izmantošanas, dažādu ḷaunatūru un izspiedējvīrusu gadījumu skaits [5]. Eiropas Savienības dalībvalstīs lielākajā dạ̦ā policijas dienestu diemžēl ir tikai viena vai dažas sevišķās nodal̦as, kas specializējušās kibernoziegumu atklāšanā, bet internetā izdarīto pārkāpumu skaits pieaug [14]. Respektīvi, gandrīz visos noziedzīgajos nodarījumos ir pierādījumi, kas saistīti ar moderno tehnolog̣iju izmantošanu, - dati tālruṇos, datoros un planšetdatoros. Informāciju, ko agrāk noziedznieki meklēja "uz ielas", tagad viṇi atrod internetā un rīkojas - sameklē ziṇas par potenciālo interneta krāpniecības vai cita noziedzīgā nodarījuma upuri, nodibina kontaktus un iegūst citus nepieciešamos datus [6].

Tādēl arī nepieciešama policijas dienestu restrukturizācija un policijas darbinieku nepārtraukta izglïtošana un zināšanu papildināšana. Valsts policijai 2017. gadā tika piešḳirti papildu līdzekḷi, valsts finansējums tika palielināts vēl par 500000 eiro, lai iegādātos tehniku un stiprinātu cilvēkresursus, kā arī tika uzsākts līdz šim vērienīgākais Iekšējās drošības fonda (IDF) projekts par kibernoziedzỉbas prevenciju un apkarošanu [16; 17]. Tieši projekta gaitā bija jāatrisina viens no lielākajiem pastāvīgajiem izaicinājumiem iedzīvotāju proaktīva informēšana par kibernoziedzības riskiem. Lai gan tradicionāli policija iedzīvotājus informē jau gadiem ilgi, sadzirdēta tā tiek visai reti. Tādēḷ bija nepieciešams izdomāt, kā pievērst iedzīvotāju uzmanību, kādas atraktīvas, modernas metodes izraudzìties. Par šā EK līdzfinansētā projekta kampaṇas “Nedalies ar svešinieku!" sākumu kḷuva sociālie eksperimenti interneta vietnē Youtube un sociālajā vietnē Facebook. Proti, tika izdomāts Imanta Hakerovska tēls, kas "ierakstīja" savu video emuāru par iedzīvotāju kiberkrāpšanas aktuālajiem veidiem. Tēlā iejutās aktieris, un tika īpaši izdomāts viṇa stils un pielāgota valoda. Izplatot šo video Youtube, tas nekavējoties kḷuva populārs un tika

${ }^{5}$ Valsts policijas mobilo aplikāciju Mana drošỉba iespējams lejupielādēt bez maksas Google Play Shop un App Apple Store. 
gan skatīts, gan pārsūtīts. Pozitīvā un reizē kampaṇai arī ne tik iepriecinošā ziṇa bija tā, ka Imanta Hakerovska uzstāšanās drīz vien tika nobloḳēta, jo saturēja informāciju, kas uzskatāma par nevēlamu, un šāda rīcība liecina par to, ka arī sociālo tīklu saturs tiek uzraudzìts. Protams, kampaṇas īstenotājiem būtu interesantāk, ja tēla popularitāte un video pārpublicēšana turpinātos... Tomēr jāpiemin, ka šis video pavisam ìsā laikā tika pārpublicēts vairākas reizes.

Otrs kampaṇas eksperiments notika sociālajā vietnē Facebook. Kampañai “Nedalies ar svešinieku!" speciāli tika radīts Janas Silas tēls. İpaši tika piedomāts un strādāts, izraugoties tēla fotogrāfijas, stāstot par interesēm un sniedzot citas profilam raksturīgas norādes (par radiem, draugiem, kā arī attēli no ceḷojumiem). Rezultāts diezgan stipri pārsteidza ne tikai Valsts policijas darbiniekus, bet arī sadarbỉbas partnerus - 1600 draugu lıti îsā laikposmā (no 20.08.2018. līdz 16.10.2018.). Izbrīnīja, ka draudzības uzaicinājumi tika apstiprināti nudien ḷoti ātri, un tikai dažkārt kāds iedomājās pajautāt, vai Janu Silu pazīst arī dzīvē. Tieši vīrieši bija tie, kas gandrīz nekad nepainteresējās, vai skaistā meitene ir satikta arī reālajā pasaulē. Šì ir tipiska prakse un raksturīga kḷūda. Diemžēl citos gadījumos, kas nav sociālie eksperimenti, tā bieži noved pie tā, ka cilvēks kḷūst par cietušo kibernoziegumā [7], apstiprināja kibernoziedzības apkarošanas eksperts Dmitrijs Homenko. ${ }^{6}$ Kampañas rezultāti iedzīvotājiem ir pieejami arī tiešsaistē Delfi vietnē [20]. Bez pavisam vienkāršiem draudzības uzaicinājumiem un apstiprinājumiem Jana Sila saṇēma arī diezgan daudz aizdomīgu vēstuḷu ar draudzības un tikšanās uzaicinājumiem reālajā dzīvē. Tā kā kampaņas mērkis aprobežojās tikai ar profila izveidi un draudzības apstiprinājumiem, rakstītājiem atbildes netika sniegtas, lai gan šādas provokācijas rezultāts varētu būt visnotal interesants, jo Jana no potenciālajiem interesentiem saṇēma 150 vēstules.

Vēl viena aktivitāte, kas notika šajā projektā, bija sociālais eksperiments sadarbībā ar televīzijas raidījumu Bez tabu. Ideja bija šāda: piedāvāt bezmaksas kafiju pret iespēju saṇemt personas datus klientu datubāzei. Piedāvājumam piekrita visai daudz jauniešu un cita vecuma cilvēku, kas pat nepajautāja anketas aizpildīšanas iemeslu. Vienlaikus informācija tika ievadīta interneta vidē, un, pasniedzot kafiju, pašam personas datu îpašniekam tika pastāstīts neliels stāsts par atrasto. Tas lika aizdomāties par iedzīvotāju atlaižu karšu aizpildīšanas paradumiem lielveikalos, kā arī par to, kādus datus par sevi internetā publiskojam paši [11]. Lai gan raidījumā paustais vēstijjums nebija īpaši jauns, tas ieguva lielu popularitāti un par policijas ieteikumiem lika aizdomāties pavisam citādā aspektā.

Datu drošība un tās saistība ar iespējamiem cilvēktiesību pārkāpumiem kḷūst par jaunu mācību priekšmetu daudzās Eiropas Savienības dalībvalstīs. Latvijā problēma ir šāda: ar nevalstisko organizāciju starpniecību, kas bieži vien jau sniedz palīdzību cietušajiem, par šiem jautājumiem sākotnēji tiek runāts kā par kaut ko īpašu, lai gan ārvalstīs tie jau kḷuvuši par pilnībā integrēta interneta drošības un personas datu aizsardzỉbas mācību kursa dạ̣u pamatskolā. Šo ceḷu sākušas iet daudzas Eiropas Savienības dalībvalstis.

${ }^{6}$ Dmitrijs Homenko - Valsts policijas Galvenās kriminālpolicijas pārvaldes Ekonomisko noziegumu apkarošanas pārvaldes 3 . nodaḷas cīnai ar kibernoziedzību priekšnieks. 
Vispārējs kurss par personisko datu aizsardzību un uzvedību internetā izstrādāts arī Eiropas Savienības līmenī, un tajā piedāvātas visdažādākās interesantu diskusiju idejas, un tās mijas ar praktiskām nodarbībām par datu aizsardzības un drošības tēmu: tiesībām uz savas informācijas aizsardzību, labošanu un nepārpublicēšanu, tiesībām sūdzēties. Šajā procesā iesaistās dažādas vietējās tiesību aizsardzības institūcijas, policija, izglìtības iestādes un personas datu aizsardzības ombudi [12].

Latvijā, îstenojot dažādus prevencijas sadarbības projektus kiberdrošības jomā, jau ilgstoši uzticams Valsts policijas sadarbības partneris ir Informācijas tehnologiiju drošības incidentu novēršanas institūcija CERT.LV un Drošāka interneta centrs, kas ne tikai piedāvā mūsdienīgu mājaslapu ar palīdzības iespējām sociālo tīklu kontu lietotājiem [15], bet arī vada praktiskas mācības pedagogiem un vecākiem, piemēram, par drošības uzstādījumiem tālruniem. Drošāka interneta centra eksperti palīdz tiem iedzīvotājiem, kas, izmantojot Valsts policijas mobilo aplikāciju Mana drošỉba, ziṇo Valsts policijai par pārkāpumiem interneta vidē. Mūsdienās aktīvi tiek izmantots arī cietušo uzticības tālrunis 116111, kas arī ir viens no pēdējo gadu laikā īstenotiem veiksmīgākajiem starpdisciplinārajiem prevencijas pasākumiem.

Plašu sabiedrības rezonansi nesen ieguva Augstākās tiesas spriedums jautājumā par to, vai drīkst vai nedrīkst filmēt policijas darbiniekus un bez saskaņošanas publiskot šos attēlus un video sociālajos tīklos. Augstākā tiesa nolēma, ka arī uz Valsts policijas darbiniekiem attiecas Personas datu aizsardzïbas regula [1], proti, bez piekrišanas attēlus izplatìt nedrīkst, un arī valsts dienesta darbiniekiem jānodrošina noteikts privātās dzīves aizsardzības līmenis - tiesības kontrolēt sava attēla izmantošanu [2]. Valsts policijā par šiem jautājumiem līdzīga diskusija bija jau 2010. gadā, kad Talsu policijas iecirkṇa darbinieki publiskoja savas fotogrāfijas pašvaldības mājaslapā, lai iedzīvotāji vinus varētu atpazìt. Tas izraisīja diskusiju pārējo novadu policijas darbinieku vidū, jo ne visi piekrita, ka viṇu fotogrāfijas tiktu ievietotas internetā. Visasāk uz šo ideju reagèja Rīgas regiona policijas darbinieki, kas vismazāk vēlējās tikt publiskoti. Jāpiebilst, ka Rīgas reg̣ionā tradicionāli ir arī viszemākā iecirkṇa inspektoru atpazīstamība - viṇus atpazīst tikai 5-10\% iedzīvotāju.

\section{Secinājumi}

Personas datu aizsardzība un kiberdrošība noteikti ir un arī turpmāk būs viens no policijas darba, kas vērsts uz sabiedrību, izaicinājumiem saistībā ar Valsts policijas prevencijas darbu. Pēdējos gados paveikts ir ḷoti daudz, bet ceḷ̆š, pa kuru jāvirzās policijai, vienmēr būs jāturpina atbilstīgi sabiedrības mainīgajām prasībām un mūsdienu tehnologijām. Svarīgs šajā virzībā ir vadības atbalsts un stratēgiskā plānošana, kurai jāturpina iedzīvināt uz sabiedrību vērsta policijas darba metodes. Vienlaikus var secināt, ka mūsdienīgu policijas darba un prevencijas metožu piemērošana ikdienas dzīvē ir atkarīga no pašiem policijas darbiniekiem un darba vērtēšanas kritērijiem, jo sekmīgi paveikts tiek tas, ko arī novērtē un par ko tiek maksāts. 
Ilze Bērziņa-Rukere. Uz sabiedrību vērsta policijas darba metodes mūsdienu mainīgajā pasaulē

\section{Modern Methods to Prevent Cybercrime in Latvia}

\section{Abstract}

Article is devoted to the topic of community policing and modern crime prevention methods in Latvia. The author is reviewing the last 10 years of work of the Latvian state police to reach a wider public about the different issues of crime prevention, including prevention and implementation of different organisational reforms, including new approaches of modern communication to tackle cybercrime. Analysis about the most challenging initiatives and projects proves that the State police has achieved considerable development in order to become a modern police service. Meanwhile, the author is acknowledging that continuous efforts and initiatives should be made to prevent and fight cybercrimes and other forms of crimes.

Keywords: community policing, State police of Latvia, crime prevention, cybercrime.

\section{Avoti un literatūra}

\section{Tiesību akti}

1. Eiropas Parlamenta un Padomes Regula (ES) 2016/679 par fizisku personu aizsardzïbu attiecībā uz personas datu apstrādi un šādu datu brīvu apriti un ar ko atceḷ Direktīvu 95/46/EK. Eiropas Savienïbas Oficiālais Vēstnesis. L 119/1, 04.05.2016. Iegūts no: https://eur-lex.europa.eu/legalcontent/LV/TXT/?uri=CELEX\%3A32016R0679 [sk. 07.06. 2019.].

\section{Tiesu prakse}

2. Augstākās tiesas 2019. gada 15. marta spriedums lietā Nr. A42050223 SKA-6/2019.

3. Administratīiās rajona tiesas Rīgas tiesu nama 2012. gada 28. decembra spriedums administrativajā lietā Nr. 142173111 (1-0913-12/26).

\section{Literatūra}

4. Iekšlietu ministrijas darbības stratēgiija. Latvijas Republikas Iekšlietu ministrija. 2018. Iegūts no: http://www.iem.gov.lv/files/text/STRATEGIJA__2019v2.pdf [sk. 04.07.2019.].

5. Internet organised crime threat assessment 2018. Europol. Iegūts no: https://www.europol. europa.eu/internet-organised-crime-threat-assessment-2018 [sk. 07.06.2019.].

6. Intervija ar Dmitriju Homenko par drošỉbu interneta vidē: LTV “Rìta Panorāma”. 17.10.2018. Youtube. Iegūts no: https://www.google.com/search?q=INTERVIJA+AR+dMITRIJU+HOMEN KO\&tbm=isch\&source $=$ iu\&ict $x=1 \&$ fir $=$ di0Zi60e3_kcQM\%253A\%252CD19NSQR4f $x 45$ cM\%25 2C_\&vet=1\&usg=AI4_-kTLKmTjot5xtbBBCg5DdEEzsWKnsA\&sa=X\&ved=2ahUKEwjDx9aF 7JvjAhWStYsKHYxzCA8Q9QEwDHoECAUQBA\#imgrc=di0Zi60e3_kcQM: [sk. 08.08.2019.].

7. Intervija ar Dmitriju Homenko par drošỉbu interneta vidē. LTV.LV 18.10.2018. Iegūts no: https:// ltv.lsm.lv/lv/raksts/18.10.2018-intervija-ar-dmitriju-homenko-par-drosibu-interneta-vide. id141979/ [sk. 08.08.2019.].

8. Landmane, D., Rinkevics, A. 2013. Pētījums: Policijas darba kvalitāte cietušā vērtējumā. Rīga. 
9. Ozolina, Ž. 2012. Cilvēkdrošība: Vai iespējams visaptverošs definējums? No: Cilvēkdrošỉba Latvijā un pasaulē: No idejas lìdz praksei. Aut. kol. Ž. Ozoliṇas red. Rīga: Zinātne. 16.-38. lpp. 10. Uz sabiedrību vērsts policijas darbs Latvijā 2009.-2012. gads. Pieredze un nākamie soḷi. Aut. kol. I. Bērziṇa-Ruḳere, I. Avota, N. Grūbis, M. Tošovskis. Rīga: Valsts policija, 2012.

11. Runce, B. 06.11.2018. "Mēs tev uzsauksim kafiju, bet tu pasaki, kā tevi sauc!": "Bez Tabu" eksperimentā atklāj, cik svešiniekam viegli piekḷūt tavai privātajai informācijai! SKATIES.LV Iegūts no: https://skaties.lv/beztabu/nejedzibas/mes-tev-uzsauksim-kafiju-bet-tu-pasaki-ka-tevi-saucbez-tabu-eksperimenta-atklaj-cik-svesiniekam-viegli-pieklut-tavai-privatajai-informacijai/ [sk. 07.08.2019.].

12. The European Handbook for Teaching Privacy and Data Protection at Schools. Fuster, G. G., Kloza, D. (eds). Brussels, 2016.

13. Valsts policija uzsāk sociālo pretnarkotiku kampaṇu jauniešiem "Tu lieto narkotikas, narkotikas lieto tevi”. Latvijas Republikas Iekšlietu ministrija. 31.08.2010. Iegūts no: http://www.iem.gov. lv/lat/aktualitates/jaunumi/?doc=18998 [sk. 07.08.2019.].

14. Valsts policijas 2018. gada pārskats. Latvijas Valsts policija. Iegūts no: http://www.vp.gov.lv/faili/ jauna_mape/vp_2018._gada_parskats.pdf [sk. 07.06.2019.].

\section{Interneta resursi}

15. Drossinternets.lv [Latvijas Drošāka interneta centra mājaslapa]. Iegūts no: https://drossinternets. $\mathrm{lv} /$ [sk. 04.07.2019.].

16. Latvijas Republikas Iekšlietu ministrija [mājaslapa]. Iegūts no: www.iem.gov.lv [sk. 04.07.2019.].

17. Latvijas Valsts policija [mājaslapa]. Iegūts no: www.vp.gov.lv [sk. 08.08.2019.].

18. Mana drošỉba [Valsts policijas Prevencijas vadības biroja izveidota mājaslapa]. 2019. Iegūts no: www.manadrosiba.lv [sk. 08.08.2019.].

19. Mobilajā lietotnē "Mana drošība" būs iespējams ziṇot par savu atrašanās vietu. TV NET.LV 29.11.2016. Iegūts no: https://www.tvnet.lv/4611710/mobilaja-lietotne-mana-drosiba-bus-iespejams-zinot-par-savu-atrasanas-vietu [sk. 04.07.2019.].

20. Nedalies ar svešinieku! Delfi. Iegūts no: https://www.delfi.lv/news/nedalies-ar-svesinieku/ [sk. 07.08.2019.].

21. Policija radījusi jaunu lietotnes rīku drošībai internetā. $L A . L V$ [ziṇu portāls Latvijai]. 07.03.2018. Iegūts no: http://www.la.lv/policija-radijusi-jaunu-lietotnes-riku-drosibai-interneta [sk. 04.07.2019.].

22. Sarunu festivāls LAMPA [mājaslapa]. Iegūts no: www.festivalslampa.lv [sk. 31.05.2019.].

23. Zvirbulis, G. 13.03.2019. Aptauja: Policijai uzticas aizvien vairāk. LSM.LV https://www.lsm.lv/ raksts/zinas/latvija/aptauja-policijai-uzticas-aizvien-vairak.a312614/ [sk. 31.05.2019.]. 